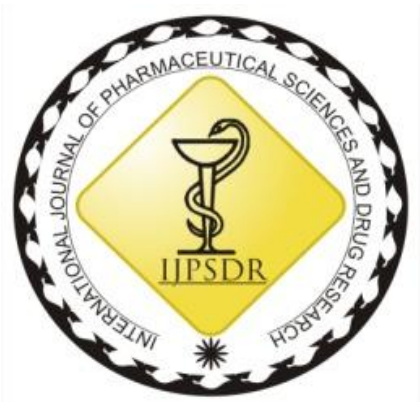

ISSN: 0975-248X

RESEARCH ARTICLE CODEN (USA): IJPSPP

$(\mathrm{cc})$ EY-NG-SA

\title{
Synthesis, Spectral Characterization and Pharmacological Significance of Cr(III) and Mn(II) Complexes with Schiff Base and Thiocyanate Ion as Ligands
}

\author{
R. Govindharaju ${ }^{1}$, P. Durairaj2 ${ }^{2}$ T. Maruthavanan ${ }^{3}$, M. Marlin Risana ${ }^{4}$, \\ T. Ramachandramoorthy ${ }^{5}$
}

1PG \& Research Department of Chemistry, Thanthai Hans Roever College (Autonomous), Perambalur-621 220, Tamil Nadu, India

${ }^{2}$ Department of Chemistry, Excel Engineering College, Pallakkapalayam, Komarapalayam, Namakkal-637 303, Tamil Nadu, India

${ }^{3}$ Department of Chemistry, Sona College of Technology, Salem-636 005, Tamil Nadu, India ${ }^{4} P G$ \& Research Department of Chemistry Government Arts College, Ariyalur-621 713, Tamil Nadu, India ${ }^{5} P G$ \& Research Department of Chemistry, Bishop Heber College (Autonomous), Tiruchirappalli- 620017 , Tamil Nadu, India

Copyright (C) 2019 R. Govindharaju et al. This is an open access article distributed under the terms of the Creative Commons AttributionNonCommercial-ShareAlike 4.0 International License which allows others to remix, tweak, and build upon the work non-commercially, as long as the author is credited and the new creations are licensed under the identical terms.

\begin{abstract}
Cr(III) and Mn(II) metal complexes of Schiff base ligand derived from phenylacetylurea condensed with salicylaldehyde (SBPS) and thiocyanate( $\mathrm{SCN}^{-}$) ion were synthesized by using microwave irradiation. Microwave assisted synthesis gives high yield of the complexes within a very short time. The molecular formulae and the geometry of the complexes have been deduced from elemental analysis, metal estimation, electrical conductance, magnetic moment, electronic spectra, FT- IR, Far IR spectra, cyclic voltammetry, thermal analysis and powder-XRD techniques. The molar conductance values indicate that the complexes are non-electrolyte (1:0) type. FT-IR spectra show that Schiff base and thiocyanate ion are coordinated to the metal ion in a monodentate manner. The electronic spectra and the magnetic moment indicate the geometry of the complexes is found to be octahedral. The antimicrobial activities of ligands and their $\mathrm{Cr}(\mathrm{III})$ and $\mathrm{Mn}$ (II) complexes were studied against the microorganisms, viz., E. coli, Klebsiella Pneumonia, P. aeruginosa, S. aureus, Bacillus cereus, Aspergillus flavus, Aspergillus niger, Aspergillus oryzae, Aspergillus sojae and Candida albicans by agar well diffusion method. The complexes show moderate activity against the bacteria and enhanced activity against the fungi as compared to free SBPS ligand. The free radical scavenging activity of the complexes and the ligands has been determined by measuring their interaction with the stable free radical, DPPH. The complexes have larger antioxidant activity as compared to the ligand. DNAbinding properties have been studied by fluorescence-emissions method. The results suggest that the complexes strongly bind to DNA because of metal complexes are well-known to speed up the drug action and the ability of a therapeutic agent which can frequently be enhanced upon coordination with a metal ion.
\end{abstract}

Keywords: SBPS, thiocyanate ion, antimicrobial, antioxidantal, DNA-binding.

DOI: 10.25004/IJPSDR.2019.110504

Int. J. Pharm. Sci. Drug Res. 2019; 11(5): 174-180

*Corresponding author: Dr. R. Govindharaju

Address: PG \& Research Department of Chemistry, Thanthai Hans Roever College (Autonomous), Perambalur-621 220, Tamil Nadu, India

E-mail $\bowtie$ : argovindh@gmail.com 


\section{INTRODUCTION}

Schiff bases and their metal complexes have been investigated for their outstanding and imperative properties, such as their ability to reversibly bind oxygen [1], catalytic activity in the hydrogenation of olefins [2], photochromic properties [3-4] and complexing ability towards a number of toxic metals. ${ }^{[5]}$ Schiff bases are a special group of ligands with a variety of donor atoms exhibiting interesting coordination modes towards various metals. ${ }^{[6-8]}$ The azomethine linkage in Schiff bases is accountable for the biological activities such as antitumor, antibacterial, antifungal and herbicidal activities. ${ }^{[9]}$ Designing a proper polydentate Schiff base ligand to combine with a metal ion along with pseudohalides anion has opened a new area of synthesizing metal complexes of particular choice. [10] Such complexes are readily assembled from diamines and various salicylaldehyde derivatives and are amenable to combinatorial syntheses. [11] Metal ions with schiff base complexes have been well known for their easy synthesis, stability and wide application. [1214] Typically, metal complexes are well-known to speed up the drug action and the competence of a therapeutic agent which can frequently be enhanced upon coordination with a metal ion. [15-16] The biological action has also been found to be highly dependent on the nature of the metal ion and the donor sequence of the ligands as different ligands reveal different biological properties. [17]

In the present study aims at synthesis and spectral characterization of $\mathrm{Cr}$ (III) and $\mathrm{Mn}$ (II) complexes with the schiff base ligand (derived from phenylacetylurea and salicylaldehyde by condensation) and thiocyanate ion. The free ligands and their prepared complexes will be characterized by the physico-chemical, spectral, antibacterial, antifungal and antioxidant and DNA binding studies.

\section{MATERIALS AND METHODS \\ Materials}

Phenylacetylurea, salicylaldehyde, potassium thiocyanate and chromium nitrate and manganese nitrate were purchased from Alfa Aaser Company and used as such. The organic solvents used, were DMSO, DMF, methanol, ethanol which were of AnalaR grade, and used as such without further purification.

\section{Preparation of Schiff base}

The schiff base was prepared by refluxing an ethanolic solution of required mole ratios of phenylacetylurea condensed with salicylaldehyde in the presence of $\mathrm{NaOH}$, for about an hour.

Synthesis of Metal Complexes

Synthesis of $\mathrm{Cr}$ (III) complex

$2.06 \mathrm{~g}(7.49 \mathrm{mmol})$ of SBPS in ethanol and $0.95 \mathrm{~g}(7.49$ $\mathrm{mmol}$ ) of potassium thiocyanate in ethanol were added to the chromium nitrate $1.00 \mathrm{~g}(2.50 \mathrm{mmol})$ in methanol followed by microwave irradiation for a few seconds after each addition by using IFB 25 BG-1S model microwave oven. The consequential precipitate was filtered off, washed with 1:1 ethanol: water mixture and desiccated under vacuum. A blue colored complex was obtained with $68.5 \%$ yield.

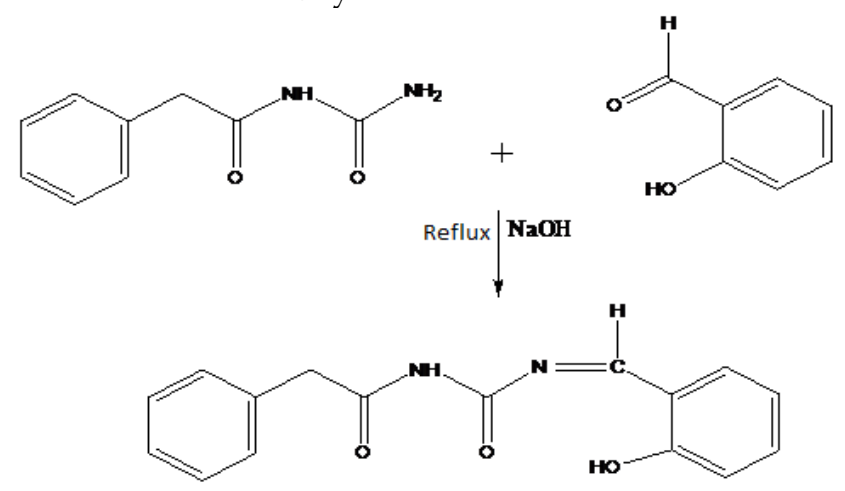

Fig. 1: Schiff Base of Phenylacetylurea condensed with Salicylaldehyde (SBPS)

\section{Synthesis of Mn(II) complex}

$4.38 \mathrm{~g}$ (15.93 mmol) of SBPS in ethanol and $1.01 \mathrm{~g}$ (7.96 $\mathrm{mmol}$ ) of potassium thiocyanate in ethanol were added to the manganese nitrate $1.00 \mathrm{~g}(3.98 \mathrm{mmol})$ in methanol followed by microwave irradiation for a few seconds after each addition by using IFB 25 BG-1S model microwave oven. The resulting impulsive was filtered off, washed with 1:1 ethanol: water mixture and dried under vacuum. A pale brown colored complex was obtained with the percentage yield of 71.8.

\section{Instrumentations}

CHN elemental analyses were performed using Thermo Finnegan make, Flash EA1112 Series CHNS(O) analyzer. The electrical conductivity measurements were conducted using $10^{-3} \mathrm{M}$ solutions of the metal complex in acetonitrile with Systronic Conductivity Bridge (model number-304) at $30^{\circ} \mathrm{C}$. The UV-Visible spectrum of the $\mathrm{Cr}(\mathrm{III})$ and $\mathrm{Mn}(\mathrm{II})$ complexes were recorded on Varian, Cary 5000 model UV Spectrophotometer. Infra red spectra for the complexes and the ligands were recorded on a Perkin Elmer, Spectrum RX-I, FT IR spectrometer in $\mathrm{KBr}$ discs at room temperature. The Far-IR Spectrum of the complex was recorded by Bruker 3000, FT IR Spectrometer. The cyclic voltammograms of the complexes were taken in acetonitrile medium using Princeton make (MC-Tech, Applied Research) equipment. Tetrabutylammonium tetrafluoroborates was used as the supporting electrolyte. The thermogravimetric analyses of the complexes were carried out using Perkin Elmer Diamond TGA/DTA Instrument. The powder X-ray diffraction analysis of a few complexes was recorded on a Rigaku model X-ray Diffractometer.

Biological activities 


\section{Antimicrobial activity}

The $\mathrm{Cr}(\mathrm{III})$ and $\mathrm{Mn}(\mathrm{II})$ complexes and the free ligand were tested for in vitro antimicrobial activity by the well diffusion method [18] using agar nutrient as the medium. The antibacterial and antifungal activities of the ligands and the complexes were evaluated by well diffusion method against the strains, cultured on potato dextrose agar as medium. The stock solution $\left(10^{-2} \mathrm{M}\right)$ was prepared by dissolving the compounds in DMSO and the solutions were successively diluted to find Minimum Inhibitory Concentration values. According to the typical procedure [19] a well was made on the agar medium inoculated with the microorganisms. The well was filled with the test solution using a micropipette and the plate was incubated for 24 hours for bacteria and 72 hours for fungi at $35^{\circ} \mathrm{C}$. At the end of the period, inhibition zones formed on the medium were evaluated in millimeters $(\mathrm{mm})$ and diameter.

\section{Antioxidant activity}

Evaluation of antioxidant Activity Stock solution $(1 \mathrm{mg} / \mathrm{ml})$ was diluted to final concentrations of 10 $500 \mu \mathrm{g} / \mathrm{ml}$. Ethanolic DPPH solution $(1 \mathrm{ml}, 0.3 \mathrm{mmol})$ was added to sample solutions in DMSO $(3 \mathrm{ml})$ at different concentrations $(10-500 \mu \mathrm{g} / \mathrm{ml})$. ${ }^{20]}$ The mixture was shaken energetically and acceptable to stand at room temperature for $30 \mathrm{~min}$. The absorbance was then measured at $517 \mathrm{~nm}$ in a UV-Vis Spectrophotometer. The lower absorbance of the reaction mixture indicates higher free radical scavenging activity. Ethanol was used as the solvent and ascorbic acid as the standard. The DPPH radical scavenging activity was designed by the following equation:

$$
\text { Scavenging effect }(\%)=\frac{A_{0}-A_{1}}{A_{0}}
$$

Where Ao is the absorbance of the control reaction and $A_{1}$ is the absorbance in the presence of the samples or standards.

\section{DNA binding studies}

The DNA binding experiments involving interaction of the complexes with calf thymus (CT)-DNA were conducted in Tris buffer containing $\mathrm{HCl}(0.01 \mathrm{M})$ adjusted to $\mathrm{pH} 7.2$ with hydrochloric acid. The CTDNA was dissolved in Tris- $\mathrm{HCl}$ buffer and was dialyzed against the same buffer overnight. Solutions of CT-DNA gave the ratios of UV absorbance at 260 and $280 \mathrm{~nm}$ above 1.8, demonstrating that the DNA was adequately free of protein. DNA concentration per nucleotide was determined by absorption spectroscopy using molar absorption coefficient $6600 \mathrm{dm}^{3} \mathrm{~mol}^{-1} \mathrm{~cm}^{-1}$ at $260 \mathrm{~nm}$. The stock solutions were stored at $4^{\circ} \mathrm{C}$ and used within 4 days. [21]

For fluorescence-quenching experiments, DNA was pre-treated with ethidium bromide $(\mathrm{EtBr})$ for 30 minutes. The copper(II) complex samples were then added to this mixture and their effect on the emission intensity was measured. Samples were excited at 450 $\mathrm{nm}$ and emission was observed between $500 \mathrm{~nm}$ and $800 \mathrm{~nm}$.

\section{RESULTS AND DISCUSSION}

\section{Elemental analysis and metal estimation}

From the elemental analytical data, the molecular formulae for the $\mathrm{Cr}$ (III) and $\mathrm{Mn}$ (II) complexes were determined. It is well consonance with the hypothetical values. The analytical data are given in the Table 1 . The experimental values are in good agreement with the theoretical values (given in the parentheses).

\section{Molar conductance}

Molar conductance measurements of the complexes carried out using acetonitrile as the solvent at the concentration of $10^{-3} \mathrm{M}$, indicates non-electrolyte [22] nature of the complexes and the conductivity values were found to be $81.51-83.17 \Omega^{-1} \mathrm{~cm}^{2} \mathrm{~mol}^{-1}$. Thus the prepared complexes are non-electrolytic nature and there is no ion present in the out of the coordination sphere.

Table 1: Elemental analysis and molar conductance

\begin{tabular}{|c|c|c|c|c|c|c|}
\hline \multirow{2}{*}{$\begin{array}{l}\text { S. } \\
\text { No. }\end{array}$} & \multirow{2}{*}{ Complex } & \multicolumn{4}{|c|}{ Elements found (Calc) \% } & \multirow{2}{*}{$\begin{array}{c}\Lambda \mathbf{m} \\
\left(\Omega^{-1} \mathbf{c m}^{2}\right. \\
\left.\mathrm{mol}^{-1}\right)\end{array}$} \\
\hline & & $\mathrm{C}$ & $\mathbf{H}$ & $\mathbf{N}$ & $\mathbf{M}$ & \\
\hline 1 & {$\left[\mathrm{Cr}(\mathrm{SBPS})_{3}(\mathrm{SCN})_{3}\right]$} & $\begin{array}{c}56.08 \\
(57.03)\end{array}$ & $\begin{array}{c}3.87 \\
(3.90)\end{array}$ & $\begin{array}{c}11.71 \\
(11.73)\end{array}$ & $\begin{array}{c}8.12 \\
(8.18)\end{array}$ & 83.17 \\
\hline 2 & {$\left[\mathrm{Mn}(\mathrm{SBPS})_{4}(\mathrm{SCN})_{2}\right]$} & $\begin{array}{c}62.50 \\
(62.53)\end{array}$ & $\begin{array}{c}4.41 \\
(4.43)\end{array}$ & $\begin{array}{c}8.72 \\
(8.73)\end{array}$ & $\begin{array}{c}4.20 \\
(4.23)\end{array}$ & 81.51 \\
\hline
\end{tabular}

\section{Magnetic moment and electronic spectra}

In the electronic spectrum of $\mathrm{Cr}$ (III) complex exhibits three absorption bands at $18518 \mathrm{~cm}^{-1}, 26954 \mathrm{~cm}^{-1}$ and $29411 \mathrm{~cm}^{-1}$, Which are assignable to the transitions ${ }^{4} \mathrm{~A}_{2 \mathrm{~g}}$ $\rightarrow{ }^{4} \mathrm{~T}_{2 g}\left(\mathrm{v}_{1}\right),{ }^{4} \mathrm{~A}_{2 g} \rightarrow{ }^{4} \mathrm{~T}_{2 g}(\mathrm{~F})\left(\mathrm{v}_{2}\right)$ and ${ }^{4} \mathrm{~A}_{2 g} \rightarrow{ }^{4} \mathrm{~T}_{1 \mathrm{~g}}(\mathrm{P})\left(\mathrm{v}_{3}\right)$ respectively indicates octahedral geometry. ${ }^{[23-24]}$ The electronic spectrum of the chromium complex reported here is in reasonable agreement with those in literature. [25] The magnetic moment at room temperature is 3.39 B.M which corresponds to the expected value for octahedral geometry of chromium complexes, involving $\mathrm{d}^{2} \mathrm{sp}^{3}$ hybridisation in the $\mathrm{Cr}(\mathrm{III})$ ion.

The electronic spectrum of $\mathrm{Mn}$ (II) complex displays the weak absorbtion bands at 15384, 17241, 27397 and $38815 \mathrm{~cm}^{-1}$ which are characteristic of octahedral geometry corresponding to the transitions, ${ }^{6} \mathrm{~A}_{1 \mathrm{~g}} \rightarrow$ ${ }^{4} \mathrm{~T}_{1 \mathrm{~g}}(\mathrm{G})\left(\mathrm{v}_{1}\right),{ }^{6} \mathrm{~A}_{1 \mathrm{~g}} \rightarrow{ }^{4} \mathrm{E}_{\mathrm{g}}(\mathrm{D})\left(\mathrm{v}_{2}\right),{ }^{6} \mathrm{~A}_{1 \mathrm{~g}} \rightarrow{ }^{4} \mathrm{~T}_{1 \mathrm{~g}}(\mathrm{P})\left(\mathrm{v}_{3}\right)$ and ${ }^{6} \mathrm{~A}_{1 \mathrm{~g}} \rightarrow{ }^{4} \mathrm{E}_{\mathrm{g}}(\mathrm{G})\left(\mathrm{v}_{4}\right)$ respectively. [26] These bands are both Laporte and spin-forbidden. However, due to instantaneous distortion of the octahedral structures around the metal cations, weak bands sometimes appear. [27-28] The magnetic moment of the complex is 4.90 B.M. This indicates the presence of Mn(II) complex in an octahedral structure and $\mathrm{d}^{2} \mathrm{sp}^{3}$ hybridization. ${ }^{[29]}$

\section{FT-IR spectra}

The FT-IR spectra of free ligands and their complexes were recorded in the region of $4000-400 \mathrm{~cm}^{-1}$. The FT-IR spectrum of the pure ligand shows the characteristic frequencies as follows: the band at $3388 \mathrm{~cm}^{-1}$ indicates the $\mathrm{v}(\mathrm{N}-\mathrm{H})$ stretching frequency of primary amine. The symmetric and asymmetric stretching frequency of $\mathrm{v}(\mathrm{N}-\mathrm{H})$ in secondary amine noticed at $1668 \mathrm{~cm}^{-1}$ and $1622 \mathrm{~cm}^{-1}$. The $\mathrm{v}(\mathrm{C}=\mathrm{O})$ stretching frequency of the 
ligand is observed at $1475 \mathrm{~cm}^{-1}$. Upon comparison, the stretching frequency of $\mathrm{v}(\mathrm{N}-\mathrm{H})$ is shifted to $1685 \mathrm{~cm}^{-1}$ and the symmetry stretching frequency at is shifted to $1605 \mathrm{~cm}^{-1}$ which confirms the entry of ligand into the coordination sphere. In addition to that, the value at $2068 \mathrm{~cm}^{-1}$ indicates the presence of $\mathrm{SCN}^{-}$in the coordination sphere of the complexes. [30-31]

\section{Far-IR Spectra}

In the Far-IR spectrum of the complexes shows, the frequency at $440-450 \mathrm{~cm}^{-1}$ corresponds to $\mathrm{HC}=\mathrm{N}$ (imine nitrogen) bond and at $342-360 \mathrm{~cm}^{-1}$ indicates the nitrogen (from thiocyanate) bond. [32]

\section{Cyclic voltammetry}

The Cr(III) complex exhibits one electron transfer quasireversible process with a reduction peak at Epc $=0.6 \mathrm{~V}$ with the corresponding oxidation peak at Epa $=1.3 \mathrm{~V}$ and the scan rate of $50 \mathrm{mV} / \mathrm{s}$. The peak separation $(\Delta \mathrm{Ep})$ of this couple is $0.7 \mathrm{~V}$. With increasing scan rates, the $\Delta \mathrm{Ep}$ value also increases giving more evidence of quasireversible $\mathrm{Cr}(\mathrm{III}) / \mathrm{Cr}(\mathrm{II})$ couple. [33]
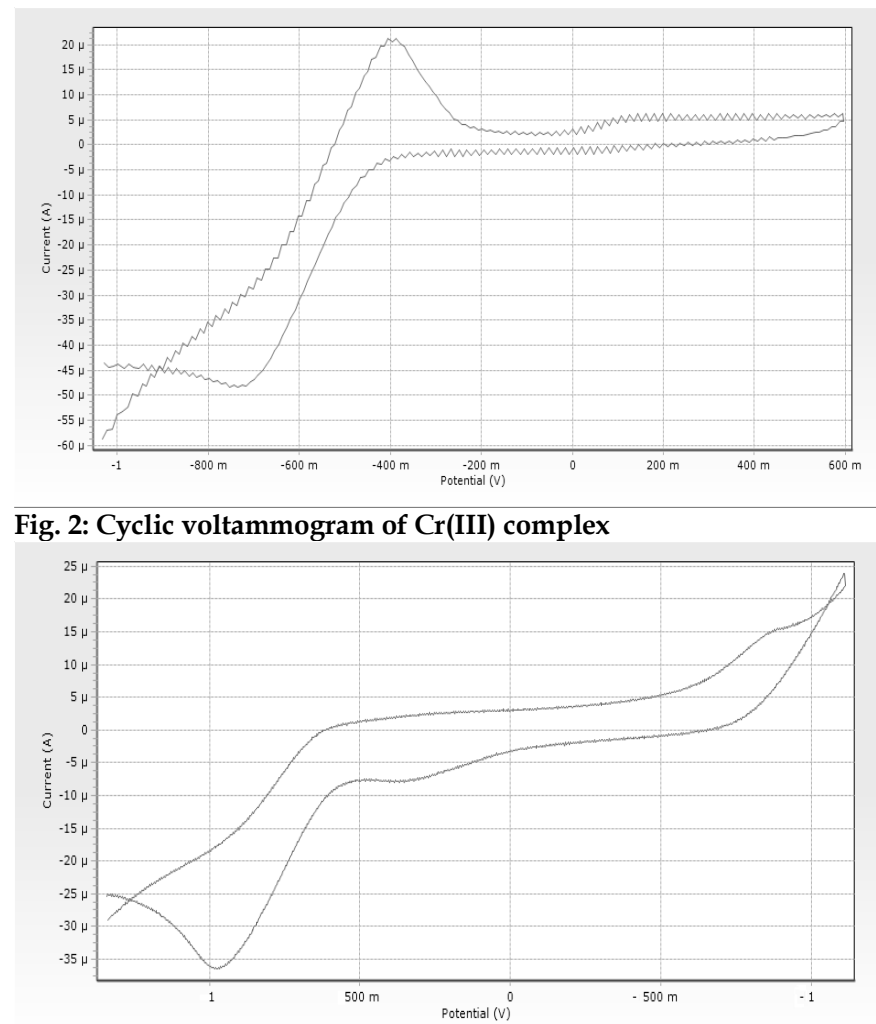

Fig. 3: Cyclic voltammogram of Mn(II) complex

The redox property of the $\mathrm{Mn}$ (II) complex has been studied in the potential range of +1.3 to $-1.3 \mathrm{~V}$ as shown in the Fig. 3. The $\mathrm{Mn}$ (II) complex is electroactive with respect to the metal center and exhibited two redox process, each reduction is associated with a singleelectron transfer process at room temperature. [34-35] Two well defined quasi-reversible one-electron cyclic responses were observed, one at $\mathrm{Epc}=0.6 \mathrm{~V}$ with corresponding oxidation peak at Epa $=0.9 \mathrm{~V}$ and the other at $\mathrm{Epc}=-0.9 \mathrm{~V}$ with the corresponding oxidation peak at $\mathrm{Epa}=-0.5 \mathrm{~V}$ respectively at the scan rate of $100 \mathrm{mV} / \mathrm{s}$.

\section{Thermogravimetric analysis}

Thermogravimetric analysis of $\mathrm{Cr}(\mathrm{III})$ and $\mathrm{Mn}(\mathrm{II})$ complexes of SBPS and thiocyanate ion show two significant temperature transitions of weight loss with common and specific stages, termed as two stages of thermal degradation. The TGA plateau of the complexes shows that these complexes exhibits no mass loss up to $190^{\circ} \mathrm{C}$, indicating the absence of coordinated water ${ }^{[36]}$ and a high thermal stability of the complexes. The weight loss at the range of $190-240^{\circ} \mathrm{C}$ in TGA curves of complexes is termed the first stage of thermal degradation. In this case, the present weight loss is in the range of (46.57-49.82\%), which may be attributed to the decomposition of less stable schiff's base. [37] The onset of second step decomposition occurs in the range of $220-280^{\circ} \mathrm{C}$, which gives the loss of thiocyanate ion (18.02 - 25.88\%) bonding with the metal complexes. The experimental values are in full agreement with the percent weight calculated on the basis of stoichiometry proposed for the complexes.

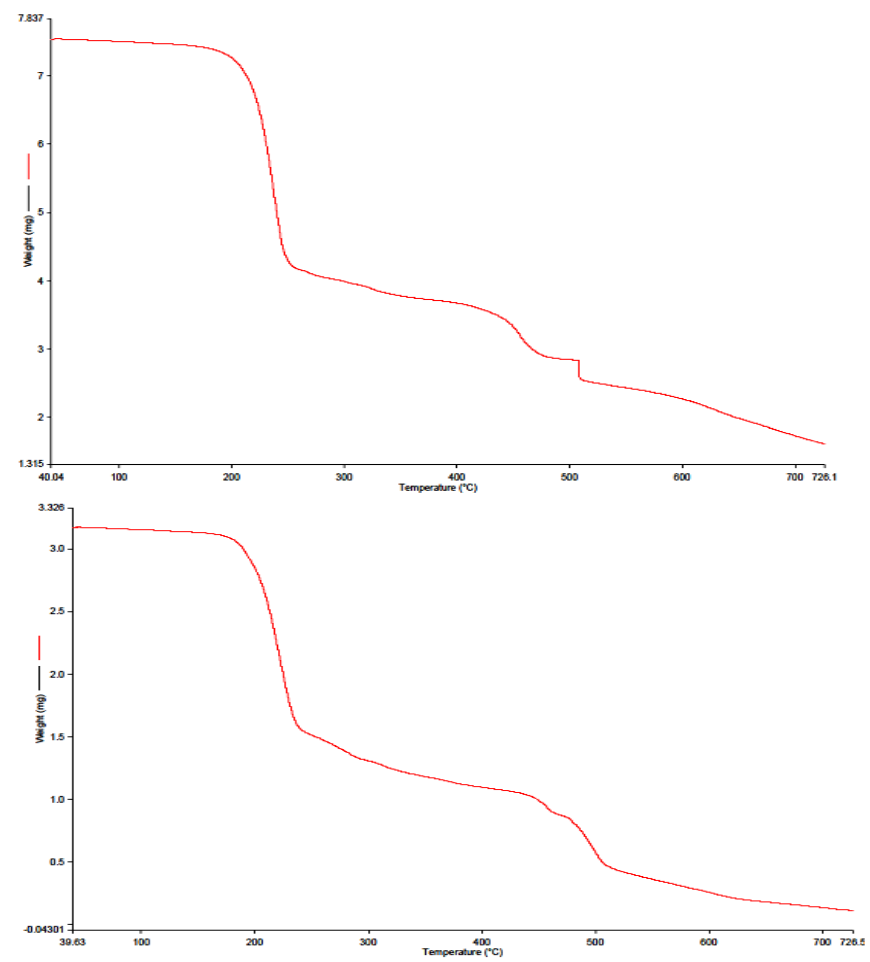

Fig. 4: Thermogram of a) $\mathrm{Cr}(\mathrm{III})$ and b) $\mathrm{Mn}$ (II) complexes

\section{Powder X-ray diffraction technique}

The Powder X-ray diffractogram of the $\mathrm{Cr}(\mathrm{III})$ and $\mathrm{Mn}$ (II) complexes were recorded in the range of $5^{\circ}$ to $80^{\circ} 2 \theta$ values. The XRD pattern indicates that the prepared complexes have well defined crystalline patterns, with various degrees of crystallinity. In these complexes, the trend of the curves decreases from maximum to minimum intensity indicating amorphous nature of the complexes. ${ }^{[38]}$ The powder XRD patterns of the synthesized $\mathrm{Cr}(\mathrm{III})$ and $\mathrm{Mn}$ (II) complexes show the sharp crystalline peaks indicating their crystalline phase. The average crystallite size $\left(\mathrm{d}_{\mathrm{XRD}}\right)$ of the complexes was calculated using Scherer's formula. ${ }^{[39-40]}$ 
The prepared complexes had an average crystallite size of 28-65 nm indicating its nanocrystalline in nature.

Biological activity

Antibacterial activity

The free ligands and their $\mathrm{Cr}$ (III) and $\mathrm{Mn}$ (II) complexes were evaluated against the bacteria E. coli, Klebsiella Pneumonia, P. aeruginosa, S. aureus, Bacillus cereus at MIC concentration using agar-well diffusion method. The complexes show enhanced activity against $P$. aeruginosa, S. aureus, Bacillus cereus and moderately active against the rest of the organisms. The increased activity of the metal complexes can be explained on the basis of chelation theory. ${ }^{41]}$ It is known that chelation tends to make the ligand act as powerful and potent bactericidal agents, killing more number of bacteria than the ligand.

Table 2: Antibacterial activity of ligands and complexes

\begin{tabular}{ccccccc}
\hline & & \multicolumn{5}{c}{ Zone of Inhibition(mm) } \\
\cline { 3 - 7 } S. & $\begin{array}{c}\text { Ligand/ } \\
\text { No }\end{array}$ & $\begin{array}{c}\text { S. } \\
\text { aureus }\end{array}$ & $\begin{array}{c}\text { Bacillus } \\
\text { cereus }\end{array}$ & $\begin{array}{c}\text { E. } \\
\text { coli }\end{array}$ & $\begin{array}{c}\boldsymbol{P} \text {. } \\
\text { aerugin } \\
\text { osa }\end{array}$ & $\begin{array}{c}\text { Klebsiel } \\
\text { la }\end{array}$ \\
\hline 1 & SBPS & 06 & 10 & 10 & 06 & 05 \\
2 & {$\left[\mathrm{Cr}(\mathrm{SBPS})_{3}(\mathrm{SCN})_{3}\right]$} & 11 & 15 & 08 & 18 & 09 \\
3 & {$\left[\mathrm{Mn}(\mathrm{SBPS})_{4}(\mathrm{SCN})_{2}\right]$} & 14 & 16 & 12 & 07 & 21 \\
\hline $05-10$ & Resistant; $11-16 \mathrm{Moderate} ; 16-21$ Highly active & \multicolumn{4}{c}{}
\end{tabular}

\section{Antifungal activity}

The synthesized $\mathrm{Cr}(\mathrm{III})$ and $\mathrm{Mn}(\mathrm{II})$ complexes and the free ligands were evaluated against the fungi, viz., Aspergillus flavus, Aspergillus niger, Aspergillus oryzae, Aspergillus sojae and Candida albicans at MIC concentration using agar-well diffusion method. The complexes show enhanced activity against the tested fungus. A comparative study of zone of inhibition diameter values of the ligands and their complexes indicate that, generally, the metal complexes have a better fungicidal activity than the free ligand. This is probably due to the greater lipophilic nature of the complexes. It is evident from the data that this activity significantly increases on coordination. [42]

Table 3: Antifungal activity of ligands and complexes

\begin{tabular}{|c|c|c|c|c|c|c|}
\hline \multirow[b]{2}{*}{$\begin{array}{l}\text { S. } \\
\text { N } \\
\mathbf{o}\end{array}$} & \multirow[b]{2}{*}{$\begin{array}{c}\text { Ligand/ } \\
\text { Complexes }\end{array}$} & \multicolumn{5}{|c|}{ Zone of Inhibition(mm) } \\
\hline & & $\begin{array}{l}\text { Aspergil } \\
\text { lus } \\
\text { Flavus }\end{array}$ & $\begin{array}{c}\text { Aspergi } \\
\text { llus } \\
\text { niger }\end{array}$ & $\begin{array}{l}\text { Aspergill } \\
\text { us oryzae }\end{array}$ & $\begin{array}{c}\text { Aspergi } \\
\text { llus } \\
\text { sojae }\end{array}$ & $\begin{array}{c}\text { Candid } \\
a \\
\text { albican } \\
\text { ce }\end{array}$ \\
\hline 1 & SBPS & 09 & 05 & 08 & 07 & 06 \\
\hline 2 & {$\left[\mathrm{Cr}(\mathrm{SBPS})_{3}(\mathrm{SCN})_{3}\right]$} & 14 & 16 & 12 & 07 & 21 \\
\hline 3 & {$\left[\mathrm{Mn}(\mathrm{SBPS})_{4}(\mathrm{SCN})_{2}\right]$} & 18 & 21 & 27 & 19 & 20 \\
\hline
\end{tabular}

\section{Antioxidant activity (Radical Scavenging Activity)}

The 2,2"-diphenyl-1-picrylhydrazyl (DPPH) radical assay provides an easy and rapid way to evaluate the antiradical activities of antioxidants. Determination of the reaction kinetic types DPPHH is a product of the reaction between $\mathrm{DPPH} \bullet$ and an antioxidant.

$(\mathrm{AH}): \mathrm{DPPH}^{\bullet}+\mathrm{AH} \rightarrow \mathrm{DPPH}-\mathrm{H}+\mathrm{A}^{\bullet}$

The reversibility of the reaction is evaluated by adding $\mathrm{DPPHH}$ at the end of the reaction. If there is an increase in the percentage of remaining $\mathrm{DPPH}^{\bullet}$ at the plateau, the reaction is reversible, otherwise it is a complete reaction. DPPH was used as stable free radical electron accepts or hydrogen radical to become a stable diamagnetic molecule. ${ }^{[43]} \mathrm{DPPH}$ is a stable free radical containing an odd electron in its structure and usually used for detection of the radical scavenging activity in chemical analysis. [44] The reduction capability of DPPH radicals was determined by decrease in its absorbance at $517 \mathrm{~nm}$ induced by antioxidants. ${ }^{45]}$ The graph was plotted with percentage scavenging effects on the yaxis and concentration $(\mu \mathrm{g} / \mathrm{ml}$.) on the x-axis. The scavenging ability of the metal complexes was compared with ascorbic acid as a standard. The metal complexes showed enhance activities as a radical scavenger compared with ascorbic acid, these results were in good agreement with previous metal complexes studies where the ligand has the antioxidant activity and it is expected that the metal moiety will increase its activity. [46]

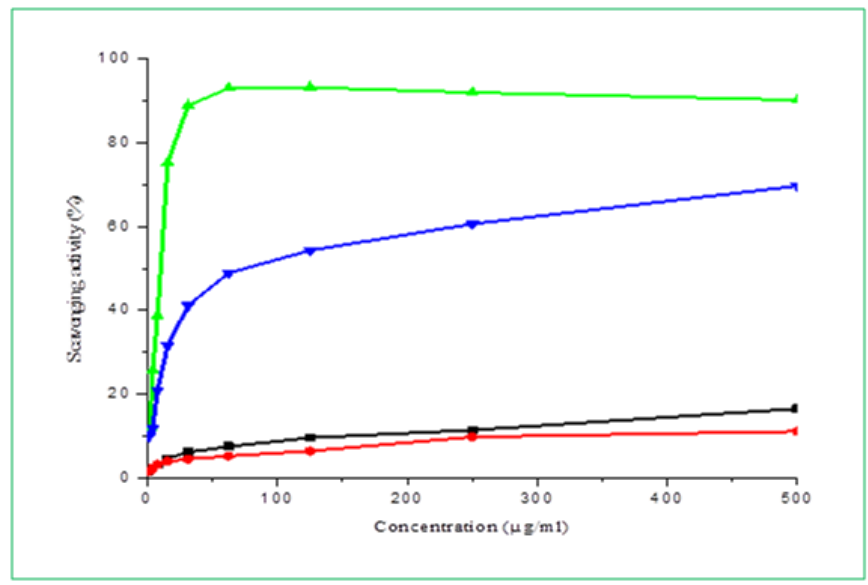

Fig. 5: Antioxidant activity of SBPS, Cr(III), Mn(II) and Vitamin C in vitro studies

\section{DNA Binding - Emission study}

As the present $\mathrm{Cr}(\mathrm{III})$ and $\mathrm{Mn}(\mathrm{II})$ complexes are nonemissive, ethidium bromide(EtBr) binding study was undertaken to gain support for the extent of binding of the complexes with DNA. Ethidium bromide (EtBr) was shown to emit intense fluorescence light in the presence of DNA, due to its strong intercalation between the adjacent DNA base pairs. It was previously reported that the fluorescent light could be quenched by the addition of a second molecule. [47] The quenching extent of the fluorescence of EtBr binding to DNA is used to determine the extent of binding between the second molecule and DNA. The addition of the complexes to DNA pretreated with EtBr causes appreciable change in the emission intensity. This behaviour can be analyzed through the Stern-Volmer equation [48], Io/I = $1+\mathrm{Ksvr}$, where Io and I are the fluorescence intensities in the absence and the presence of complex respectively. Ksv is a linear Stern-Volmer quenching constant, $r$ is the ratio of the total concentration of complex to that of DNA. The quenching plot illustrates that the quenching of EtBr bound DNA by the $\mathrm{Cr}$ (III) and $\mathrm{Mn}$ (II) complexes is in good agreement with the linear Stern-Volmer equation, 
which also indicates that the complex binds to DNA. In the plot of Io/I versus [Complex]/[DNA], Ksv is given by the ratio of the slope to intercept. The Ksv value for SBPS, $\mathrm{Cr}(\mathrm{III})$ and $\mathrm{Mn}(\mathrm{II})$ complexes thus obtained is $0.43,1.05$ and 1.43 respectively. This suggests that prepared complexes bind strongly with DNA, which is also consistent with our absorption spectral result. It is generally agreed that strong fluorescence decrement accompanies a strong interaction of the complexes with calf thymus DNA. Since, the studies have shown that macrocyclic complexes can interact with DNA in different binding fashions and exhibit effective nuclease activities. ${ }^{[49-50]}$ In recent years, binding studies of transition metal complexes have become very important in the expansion of DNA molecule probes and chemotherapeutics. [51]

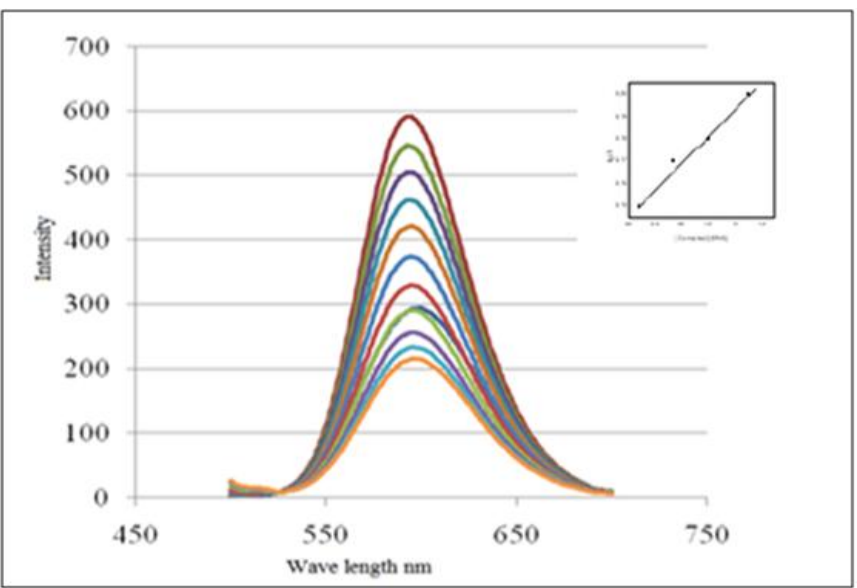

Fig. 6: Emission spectrum of EtBr bound to DNA in the absence and presence of $\mathrm{Cr}(\mathrm{III})$ complex

In the present study, our efforts were to synthesize and characterize the $\mathrm{Cr}$ (III) and $\mathrm{Mn}$ (II) metal complexes with the schiff base and thiocyanate ion as ligands. The new complexes were synthesized by using microwave irradiation. The synthesized metal complexes were characterized by various physico-chemical and spectral analyses. Based on the analytical, electrical conductance, spectral and magnetic moment, octahedral geometry has been suggested for the $\mathrm{Cr}$ (III) and $\mathrm{Mn}(\mathrm{II})$ complexes. The synthesized complexes were tested for antimicrobial activities. The metal complexes were significant antimicrobial and antioxidant activities as compared to the free ligands. The effectiveness of the DNA binding of the complexes is being confirmed by means of change in intensity of emission in the case of emission spectral studies.

\section{ACKNOWLEDGEMENT}

The authors thank the Management and the Principals of Thanthai Hans Roever College (Autonomous), Perambalur, Tamil Nadu, India for permitting them to carry out this work. The authors are also thankful the Heads, SAIF, IIT Madras, IIT Roorkee, IIT Mumbai and the Director, STIC, Cochin for providing the spectral data collection.

\section{REFERENCES}

1. Chen D, Martell AE. Dioxygen affinities of synthetic cobalt Schiff base complexes. Inorganic chemistry. 1987; 26(7):102630 .

2. Hegedus LS. Transition metals in the synthesis of complex organic molecules. University Science Books; 1999.

3. Zhao J, Zhao B, Liu J, Xu W, Wang Z. Spectroscopy study on the photochromism of Schiff Bases N, N'-bis (salicylidene)-1, 2-diaminoethane and $\mathrm{N}, \mathrm{N}$-bis (salicylidene)-1, 6hexanediamine. Spectrochimica Acta Part A: Molecular and Biomolecular Spectroscopy. 2001;57(1):149-54.

4. Zgierski MZ, Grabowska A. Theoretical approach to photochromism of aromatic Schiff bases: A minimal chromophore salicylidene methylamine. The Journal of Chemical Physics. 2000;113(18):7845-52.

5. Sawodny W, Riederer M. Addition Compounds with Polymeric Chromium(II)-Schiff Base Complexes. Angewandte Chemie International Edition in English. 1977;16(12):859-60.

6. Panda BK, Chakravorty A. Carbonylation of four-membered ruthenium and osmium metallacycles incorporating an orthometallated phenolic function: New acylruthenium and arylosmium complexes. Journal of organometallic chemistry. 2005;690(13):3169-75.

7. Krishnapriya KR, Kandaswamy M. Coordination properties of a dicompartmental ligand with tetra-and hexadentate coordination sites towards copper (II) and nickel (II) ions. Polyhedron. 2005;24(1):113-20.

8. Kumar DS, Alexander V. Synthesis of lanthanide (III) complexes of chloro-and bromo substituted 18-membered tetraaza macrocycles. Polyhedron. 1999;18(11):1561-8.

9. Rekha S, Nagasundara KR. Complexes of the Schiff base derived from 4-aminophenyl benzimidazole and 2, 2'dehydropyrollidene-N-aldehyde with Zn (II), Cd (II) and Hg (II) halides.(2006).

10. Cotton FA, Wilkinson G, Murillo CA, Bochmann M, Grimes R. Advanced inorganic chemistry. New York: Wiley; 1988.

11. Shearer JM, Rokita SE. Diamine preparation for synthesis of a water soluble $\mathrm{Ni}(\mathrm{II})$ salen complex. Bioorganic \& medicinal chemistry letters. 1999;9(3):501-4.

12. Singh K, Barwa MS, Tyagi P. Synthesis, characterization and biological studies of $\mathrm{Co}(\mathrm{II}), \mathrm{Ni}(\mathrm{II}), \mathrm{Cu}(\mathrm{II})$ and $\mathrm{Zn}$ (II) complexes with bidentate Schiff bases derived by heterocyclic ketone. European Journal of Medicinal Chemistry. 2006;41(1):147-53

13. Majumder A, Rosair GM, Mallick A, Chattopadhyay N, Mitra S. Synthesis, structures and fluorescence of nickel, zinc and cadmium complexes with the N, N, O-tridentate Schiff base $\mathrm{N}$-2-pyridylmethylidene-2-hydroxy-phenylamine. Polyhedron. 2006;25(8):1753-62.

14. Freiría A, Bastida R, Valencia L, Macías A, Lodeiro C, Adams H. Metal complexes with two tri-aza, tri-oxa pendant-armed macrocyclic ligands: Synthesis, characterization, crystal structures and fluorescence studies. Inorganica chimica acta. 2006;359(8):2383-94.

15. Wu JZ, Ye BH, Wang L, Ji LN, Zhou JY, Li RH, Zhou ZY. Bis (2, 2'-bipyridine) ruthenium (II) complexes with imidazo [4, 5-f][1, 10]-phenanthroline or 2-phenylimidazo [4, 5-f][1, 10] phenanthroline. Journal of the Chemical Society, Dalton Transactions. 1997;(8):1395-402.

16. Delaney S, Pascaly M, Bhattacharya PK, Han K, Barton JK. Oxidative damage by ruthenium complexes containing the dipyridophenazine ligand or its derivatives: a focus on intercalation. Inorganic chemistry. 2002;41(7):1966-74.

17. Goldstein BM, Barton JK, Berman HM. Crystal and molecular structure of a chiral-specific DNA-binding agent: tris (4, 7diphenyl-1, 10-phenanthroline) ruthenium(II). Inorganic chemistry. 1986;25(6):842-7.

18. Adedayo O, Anderson WA, Moo-Young M, Snieckus V, Patil PA, Kolawole DO. Phytochemistry and antibacterial activity of Senna alata flower. Pharmaceutical biology. 2001;39(6):40812. 
19. Pelczar MJ, Chan ECS and Krieg NR.Microbiology, Blackwell Science, New York, 5th edn., 1998.

20. Chen Y, Wang M, Rosen RT, Ho CT. 2, 2-Diphenyl-1picrylhydrazyl radical-scavenging active components from Polygonum multiflorum Thunb. Journal of agricultural and food chemistry. 1999;47(6):2226-8.

21. Raman N, Johnson Raja S, Sakthivel A. Transition metal complexes with Schiff-base ligands:4-aminoantipyrine based derivatives-a review. Journal of Coordination Chemistry. 2009;62(5):691-709.

22. Geary WJ. The use of conductivity measurements in organic solvents for the characterisation of coordination compounds. Coordination Chemistry Reviews. 1971;7(1):81-122.

23. Dos Santos JE, Dockal ER, Cavalheiro ÉT. Thermal behavior of Schiff bases from chitosan. Journal of thermal analysis and calorimetry. 2005;79(2):243-8.

24. Islam MR, Shampa JA, Kudrat-E-Zahan M, Haque MM, Reza Y. Investigation on spectroscopic, thermal and antimicrobial activity of newly synthesized binuclear $\mathrm{Cr}$ (III) metal ion complex. Journal of Scientific Research. 2016;8(2):181-9.

25. Cotton FA, Wilkinson G, Murillo CA, Bochmann M, Grimes R. Advanced inorganic chemistry. New York: Wiley; 1988.

26. Kulkarni AD, Patil SA, Badami PS. Electrochemical properties of some transition metal complexes: synthesis, characterization and in-vitro antimicrobial studies of Co (II) $\mathrm{Ni}(\mathrm{II}), \mathrm{Cu}(\mathrm{II}), \mathrm{Mn}(\mathrm{II})$ and $\mathrm{Fe}(\mathrm{III})$ complexes. International Journal of Electrochemical Science. 2009;4(5):717-29.

27. Bailer JC, Emeleus HJ, Nyholm R, Trotman-Dickinson A F. Comprehensive Inorganic Chemistry; Pergamon Press: Oxford, UK, 1975; pp. 517, 1153, 1088, 1048.

28. Figgs BN, Introduction to Ligand Field, Wiley, New York, NY, USA, 1966

29. Mahmoud WH, Deghadi RG, Mohamed GG. Novel Schiff base ligand and its metal complexes with some transition elements. Synthesis, spectroscopic, thermal analysis, antimicrobial and in vitro anticancer activity. Applied Organometallic Chemistry. 2016;30(4):221-30.

30. Kartha VB, Patel ND. Infrared spectra of salicylaldehyde complexes of some alkali metals. InProceedings of the Indian Academy of Sciences-Section A.1967;66(6):319-324.

31. Govindharaju R, Balasubramaniyan S, Palanivelan L, Rajasekar K, Ramachandramoorthy T. Preparation, spectral characterization, thermal stability and biological activities of $\mathrm{Mn}(\mathrm{II})$ complex with 2-aminobenzonitrile and octanoate. World Journal of Pharmaceutical Research, 2014;3(8): 788-795.

32. Wang CC, Wang P, Feng LL. Influence of organic carboxylic acids on self-assembly of silver(I) complexes containing 1, 2bis (4-pyridyl) ethane ligands. Transition Metal Chemistry. 2012;37(2):225-34

33. Govindharaju R, Balasubramaniyan $\mathrm{S}$, Rajasekar $\mathrm{K}$, Palanivelan L, Ramachandramoorthy T. Synthesis, Spectral Characterization and Biological activities of Cd(II) complex with 2-aminobenzonitrile and octanoate ion as Ligands. Journal of Applied Chemistry.2016;9(5):37-41.

34. Mohamed GG, El-Wahab ZH. Mixed ligand complexes of bis (phenylimine) Schiff base ligands incorporating pyridinium moiety: Synthesis, characterization and antibacterial activity. Spectrochimica Acta Part A: Molecular and Biomolecular Spectroscopy. 2005;61(6):1059-68.

35. Ma S, Wang XS, Collier CD, Manis ES, Zhou HC. Ultramicroporous Metal- Organic Framework Based on 9, 10-Anthracenedicarboxylate for Selective Gas Adsorption. Inorganic chemistry. 2007;46(21):8499-501.
36. Nakamoto K, Infrared and Raman Spectra of Inorganic and Coordination Compounds. Wiley, New Jersey, NJ, 2009.

37. Chohan ZH, Munawar A, Supuran CT. Transition metal ion complexes of Schiff-bases. Synthesis, characterization and antibacterial properties. Metal-based drugs. 2001;8(3):137-43.

38. Yee EL, Cave RJ, Guyer KL, Tyma PD, Weaver MJ. A Survey of Ligand Effects upon the Reaction Entropies of Some Transition Metal Redox Couples. J. Am. Chem. Soc. 1979; 101(5):1131-1137.

39. Donzello MP, Dini D, DArcangelo G, Ercolani C, Zhan R, Ou Z, Stuzhin, PA, Kadish KM. New Metal Complexes, General Physicochemical Data, Ultraviolet- Visible Linear and Optical Limiting Behavior and Electrochemical and Spectroelectrochemical Properties. Journal of the American Chemical Society, 2003;125(46):14190-14204.

40. Jabbar MA, Kabir MH, Chowdhury RA. Influence Of Caffeine On The Redox Characteristics Of Iron In Aqueous Solution. Journal of the Bangladesh Chemical Society. 2012;25(2):166-79.

41. Munde AS, Jagdale AN, Jadhav SM, Chondhekar TK. Synthesis and characterization of some transition metal complexes of unsymmetrical tetradentate Schiff base ligand. Journal of the Korean Chemical Society. 2009;53(4):407-14.

42. Naik HS, Chetana PR, Revanasiddappa HD. Synthesis, spectral and thermal degradation kinetics of divalent cadmium complexes of dothiepine and diphenhydramine. Turkish Journal of Chemistry. 2002; 26(4):565-72.

43. Turkoglu O, Soylak M, Belenli I. Electrical conductivity of chloro (phenyl) glyoxime and its $\mathrm{Co}(\mathrm{II}), \mathrm{Ni}(\mathrm{II})$ and $\mathrm{Cu}(\mathrm{II})$ complexes. Collection of Czechoslovak chemical communications. 2003;68(7):1233-42.

44. Howe-Grant M, Wu KC, Bauer WR, Lippard SJ. Binding of platinum and palladium metallointercalation reagents and antitumor drugs to closed and open DNAs. Biochemistry. 1976;15(19):4339-46.

45. Gao E, Zhu M, Yin $\mathrm{H}$, Liu L, Wu Q, Sun Y. Synthesis, characterization, interaction with DNA and cytotoxicity in vitro of dinuclear $\mathrm{Pd}(\mathrm{II})$ and $\mathrm{Pt}(\mathrm{II})$ complexes dibridged by 2 , 2'-azanediyldibenzoic acid. Journal of inorganic biochemistry. 2008;102(10):1958-64.

46. Dey S, Sarkar S, Paul H, Zangrando E, Chattopadhyay P. Copper(II) complex with tridentate $\mathrm{N}$ donor ligand: synthesis, crystal structure, reactivity and DNA binding study. Polyhedron. 2010;29(6):1583-7.

47. Wu H, Jia F, Kou F, Liu B, Yuan J, Bai Y. A Schiff base ligand $\mathrm{N}$-(2-hydroxylacetophenone)-3-oxapentane-1, 5-diamine and its nickel(II) complex: synthesis, crystal structure, antioxidation, and DNA-binding properties. Transition Metal Chemistry. 2011;36(8):847-53.

48. Stang PJ, Olenyuk B. Self-assembly, symmetry, and molecular architecture: Coordination as the motif in the rational design of supramolecular metallacyclic polygons and polyhedra. Accounts of chemical research. 1997;30(12):502-18.

49. Yuan L, Lu XH, Xiao X, Zhai T, Dai J, Zhang F, Hu B, Wang X, Gong L, Chen J, Hu C. Flexible solid-state supercapacitors based on carbon nanoparticles/MnO2 nanorods hybrid structure. ACS nano. 2011;6(1):656-61.

50. Liu J, Lu TB, Deng H, Ji LN, Qu LH, Zhou H. Synthesis, DNA-binding and cleavage studies of macrocyclic copper(II) complexes. Transition metal chemistry. 2003;28(1):116-21.

51. Boerner LJ, Zaleski JM. Metal complex-DNA interactions: from transcription inhibition to photoactivated cleavage. Current opinion in chemical biology. 2005;9(2):135-44. 